\title{
A new Wenlock retiolitid (Graptolithina) Virgellograptus from the East European Platform, Poland
}

\author{
ANNA KOZŁOWSKA
}

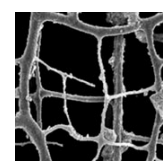

\begin{abstract}
A new retiolitid genus Virgellograptus, with a single species V. perrarus from the upper Wenlock, Cyrtograptus ellesi Biozone from Poland is described. Unlike all other retiolitids, the new form has the virgella, an axis of the sicula, connected into lateral wall of the ancora sleeve. Virgella attaches the mid-lateral list of the ancora sleeve, from which the horizontal lists are going to pleural lists and lateral apertural rods. The connection is on the obverse side of tubarium. Virgellograptus gen. nov. has a free nema, which is not preserved, at the same time it has well developed genicular lists of thecae, regarded as advanced feature. The new form is the most similar to Sokolovograptus; the key difference is a development of the proximal end - the connection of the sicula to the lateral wall of the ancora sleeve. - Key words: Graptolithina, retiolitids, Virgellograptus, Sokolovograptus, proximal end, virgella, Silurian.
\end{abstract}

KozŁOWSKA, A. 2015. A new Wenlock retiolitid (Graptolithina) Virgellograptus from the East European Platform, Poland. Bulletin of Geosciences 90(2), 453-459 (8 figures, 1 table). Czech Geological Survey, Prague. ISSN 1214-1119. Manuscript received November 13, 2014; accepted in revised form February 18, 2015; published online March 12, 2015; issued March 23, 2015.

Anna Kozłowska, Instytut Paleobiologii PAN, ul. Twarda 51/55, PL-00-818 Warszawa, Poland; akd@twarda.pan.pl

The retiolitids are unlike all other graptolites in that most possess double lateral walls: an inner one being the homologue of the "normal" diplograptoid thecal walls, and an outer wall derived entirely from the distal extension of the ancora named ancora sleeve wall (e.g. Bates \& Kirk 1984, Bates 1990, Bates et al. 2005). These walls, built from very thin and incrementally deposited fusellar layers supported by strong lists formed exclusively from bandages, are only very rarely completely preserved. Normally, therefore, only the cable-like, bandaged lists of the retiolitid rhabdosome (tubarium) are preserved.

Early investigations of retiolitids began with flattened material on rock surface (e.g. Barrande 1850, Lapworth 1879, Bouček \& Münch 1952); later turned to isolated material (e.g. Holm 1890; Münch 1931; Eisenack 1951; Obut \& Zaslavskaya 1976; Lenz \& Melchin 1987; Bates \& Kirk 1984, 1992, 1997; Lenz 1993; Kozłowska-Dawidziuk 1995, 1997; Lenz \& Kozłowska 2006).

Scanning electron microscopy provided an opportunity to better understand the construction of the tubaria and the details of the retiolitid morphology. Three-dimensional retiolitids have come mostly from the Arctic Canada (Lenz 1993, 1994a, b; Lenz \& Kozłowska-Dawidziuk 2001, 2002, 2004; Lenz et al. 2012), Poland (KozłowskaDawidziuk 1990, 1995, 2001; Kozłowska et al. 2009), Germany (Maletz 2008, 2010), and from Lithuania
(Kozłowska \& Radzevičius 2013). The new form described herein comes from the East European Platform of Poland, from where the numerous well-preserved retiolitids have already been described. Through these more recent studies, the recognized taxonomic diversity among the retiolitids has increased tremendously.

The purpose of this paper is to describe a new Wenlock retiolitid, Virgellograptus gen. nov., with a unique feature among retiolitids in that the virgella is incorporated into the lateral wall of ancora sleeve.

Unlike in all previously known retiolitids, the sicula in the new material is connected to the lateral wall of the tubarium and the nema is free within the center of the colony. Other retiolitids exhibit a free sicula and a nema that is either incorporated into lateral wall or is also free. Thus the unusual proximal end structure created a unique retiolitid tubarium, herein observed for the first time.

\section{Systematic palaeontology}

Morphological terminology after Bates et al. (2005). The new terms "proximal mid-lateral list" and "horizontal lists" for ancora sleeve lists are introduced. The proximal mid-lateral list (proximal m-1 list) attaches the virgella and is the main list of the proximal part of the obverse side of 
the ancora sleeve. This list is attached to the virgella. Horizontal lists link the proximal m-l list directly with the pleural lists and the lateral apertural rods. The classification of the retiolitines follows Melchin et al. (2011).

Superfamily Retiolitoidea Lapworth, 1873

Family Retiolitidae Lapworth, 1873

Subfamily Retiolitinae Lapworth, 1873

\section{Genus Virgellograptus gen. nov.}

Type and only species. - Virgellograptus perrarus gen. et sp. nov.

Etymology. - Virgello- after virgella, to point out its unusual connection to lateral wall of tubarium, the ancora sleeve, a feature unknown in any other retiolitids.

Diagnosis. - Ancora umbrella small with four meshes, usually complete rim. Virgella connected to proximal mid-lateral list, main list on proximal part of obverse side of ancora sleeve. Horizontal lists going from mid-lateral list to pleural lists and lateral apertural rods. Sicula long, nema free throughout. Proximal lateral and ventral orifices are overgrown by reticulum in mature colony. Lateral wall on reverse side of tubarium built of stronger oblique lists. Ventral walls composed of distinctive lips, genicular lists, pleural lists. Reticulum well developed in mature specimens.

Remarks. - Early astogenetic patterns are regarded as important for the classification of graptolites (Mitchell 1987). The connection of the virgella to the lateral wall of ancora sleeve in Virgellograptus gen. nov. becomes the new feature in the primordial evolutionary development in retiolitids.

Virgellograptus perrarus gen. et sp. nov.

Figures 1, 2, 3A, C

2013 Sokolovograptus sp. 1; Dobrowolska, pp. 170-172, pl. 4 , fig. 21.

Type material. - Holotype ZPAL G.52/1, mature specimen with three pairs of thecae (Fig. 1E).

Type locality. - Bartoszyce IG-1 borehole, $1726.5 \mathrm{~m}$, geographic coordinates $54^{\circ} 14^{\prime} \mathrm{N}, 20^{\circ} 57^{\prime} \mathrm{S}$, Poland, East European Platform.

Material. - The investigated material comes from laminated marls, Bartoszyce IG-1 core, eastern part of the Baltica, Peribaltic Syncline of the EEP, Poland, from depths:
$1725.0 \mathrm{~m}, 1726.5 \mathrm{~m}$, and $1727.9 \mathrm{~m}$. According to Tomczyk (1974) the investigated level belongs to the Wenlock, upper Sheinwoodian, Cyrtograptus ellesi Biozone, determined from 1723.5 to $1730.0 \mathrm{~m}$. This biozone is correlated with the upper part of $C$. perneri Biozone according to Loydell (2012).

Specimens are well preserved, slightly flattened and slightly squashed in different directions. Ten almost complete specimens with three pairs of thecae, one specimen with four pairs, and 20 fragments come from $1727.9 \mathrm{~m}$; eleven specimens from $1726.5 \mathrm{~m}$, mostly young and fragmentary; three specimens from $1725.0 \mathrm{~m}$. The material that Dobrowolska (2013) described as Sokolovograptus sp. 1 from Gołdap IG-1 core, also appears to belong to $V$. perrarus gen. et sp. nov. This collection contains dozens of fragments of specimens; the longest have three pairs of thecae. The specimens from both localities represent similar preservation and the same characters and measurements. Specimens from Gołdap IG-1 core occur in the Cyrtograptus lundgreni Biozone whereas those from the Bartoszyce IG-1, occur in the older, Cyrtograptus ellesi Biozone.

Material was isolated from rock following slow dissolution in 1-10\% $\mathrm{HCl}$ (see Kozłowska \& Urbanek 2013). The specimens are stored in glycerine in plastic containers, and on SEM stubs in the Institute of Paleobiology, Polish Academy of Sciences in Warsaw.

Etymology. - The Latin perrarus means very rare, exceptional.

Diagnosis. - As for the genus.

Description. - Tubarium parallel sided, width about $1.2 \mathrm{~mm}$ (Figs 1-3). The largest specimen contains five pairs of thecae (Fig. 2C, D). Length of the tubarium from the ancora to the lip of th $1^{1}$ is about $0.9 \mathrm{~mm}$, to the lip of $1^{2}$ about $1.5 \mathrm{~mm}$. The distances between thecal lips are about $750 \mu \mathrm{m}$.

In the proximal part of the lateral wall of the reverse side the distance between the pleural lists is about $560 \mu \mathrm{m}$. The obverse side is wider and has about $1 \mathrm{~mm}$. Seams inside the lists (Fig. 1A, 2E), pustules on bandages (Fig. 1A, C). Above the last horizontal lists of both lateral walls of the ancora sleeve have the similar width, about $530 \mu \mathrm{m}$.

Ancora umbrella small with four meshes (Figs 1D, G, 2B), usually not complete rim. Mesh of ancora umbrella placed on the th $1^{2}$ side of the tubarium is smaller than on th $1^{1}$ side. Pleural lists connected to the ancora umbrella located asymmetrically, what makes the obverse side of the tubarium wider (Fig. 2B).

Proximal part of lateral wall of obverse side of ancora sleeve is composed of reticulum, vertical m-l list and the horizontal lists, which go from m-1 list directly to pleural 


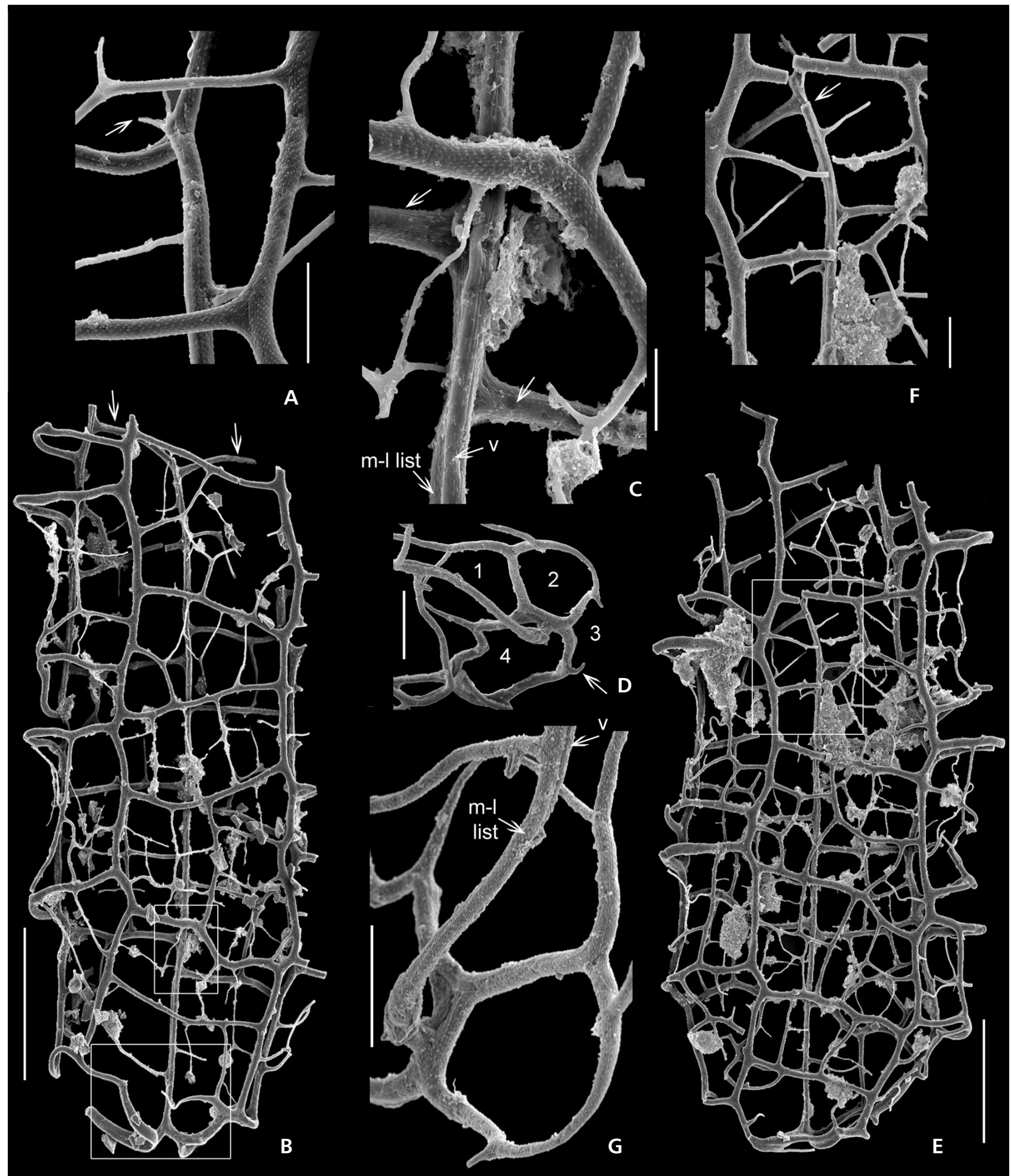

Figure 1. SEM pictures of mature specimens of Virgellograptus perrarus gen. et sp. nov., $1726.5 \mathrm{~m}$, Bartoszyce IG-1 drill core, Poland. • A - enlargement of specimen ZPAL G.52/3 showing fragment of prosicular rim (arrow). B-D - fragment of tubarium with three pairs of thecae, reverse view, latero-ventral side, ZPAL G.52/2, B - whole specimen, C - details of B showing mid-lateral list, virgella and virgellar lists, arrows. $\bullet$ E, F - fragment of tubarium with three pairs of thecae, reverse view, lateral side, ZPAL G.52/1, holotype; E - whole specimen, genicular list of th $3^{1}$ arrowed, F - details of E showing broken virgella, distal end (arrow). $\bullet \mathrm{D}, \mathrm{G}$ - ancora umbrella, view from inside, specimen ZPAL G.52/6; D - whole ancora, arrow shows unfinished edge of the mesh, numbers indicate ancora umbrella meshes, $\mathrm{G}$ - enlargement. Abbreviations: $\mathrm{m}-1$ list - mid-lateral list, $\mathrm{v}$ - virgella. Scale bars $100 \mu \mathrm{m}$ for $\mathrm{A}, \mathrm{C}, \mathrm{D}, \mathrm{F}, \mathrm{G}$ and $500 \mu \mathrm{m}$ for B, E. 

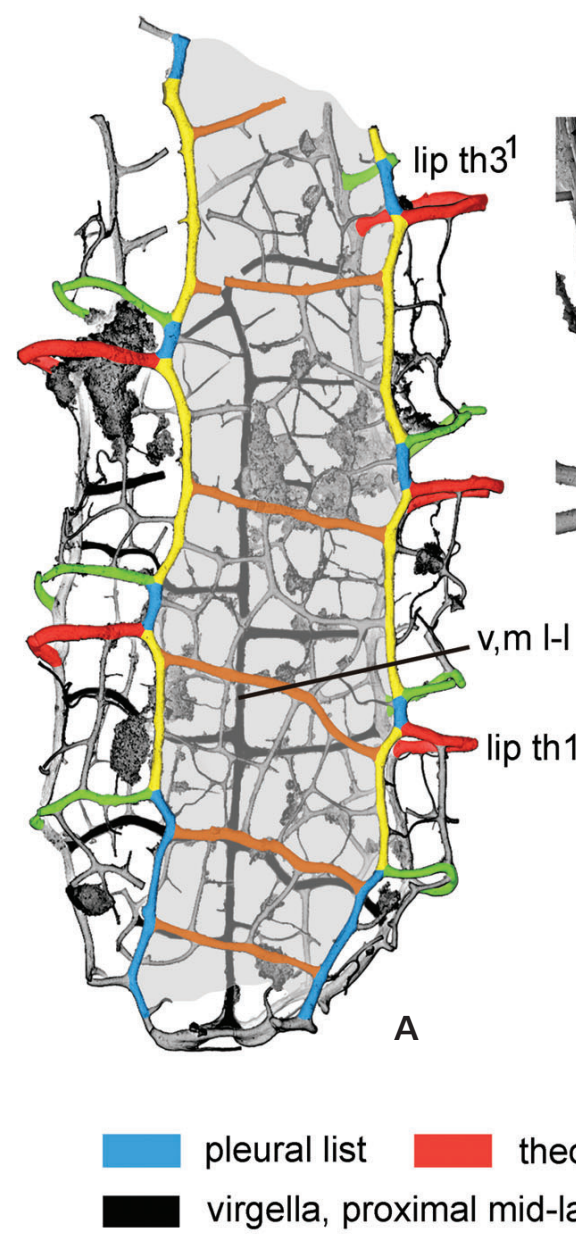

pleural list
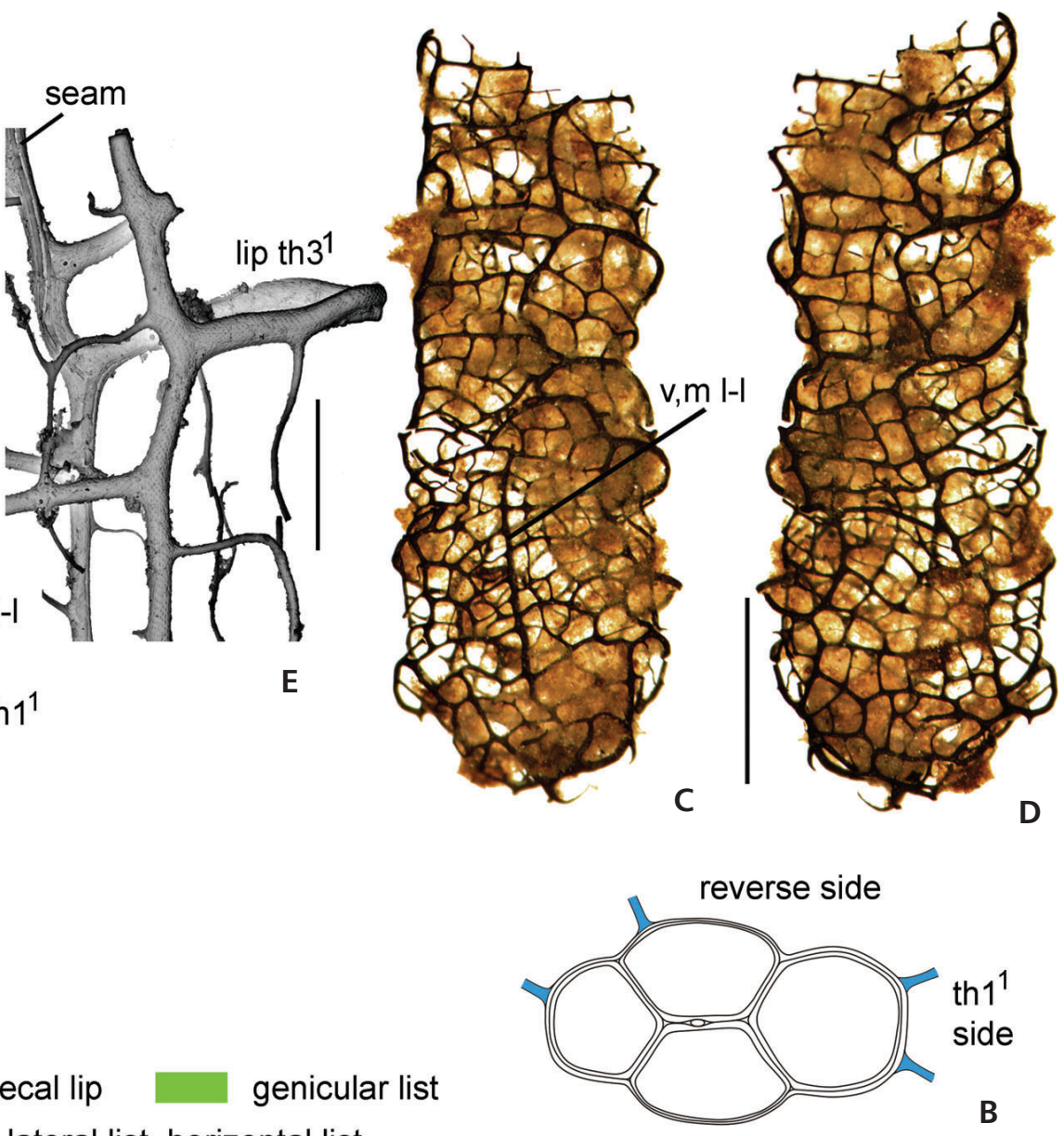

virgella, proximal mid-lateral list, horizontal list

lateral apertural rod

oblique lists

ancora sleeve membrane

Figure 2. A, E-tubarium of Virgellograptus perrarus gen. et sp. nov., ZPAL G.52/1, 1726.5 m, Bartoszyce IG-1 drill core, Poland, reverse view with some broken horizontal lists reconstructed; A - whole specimen; E- enlargement of th $3^{1} \cdot \bullet \mathrm{B}$ - sketch of idealized ancora umbrella with four meshes of Virgellograptus perrarus gen. et sp. nov. • C, D - light photos of mature Virgellograptus perrarus gen. et sp. nov. from Bartoszyce IG-1 drill core, 1727.9 m, Cyrtograptus ellesi Biozone, ZPAL G.52/6, slightly squashed specimen with five pairs of thecae, C-obverse view showing virgella connected to lateral wall, D - reverse view. Abbreviations: m-1 1- mid-lateral list, v - virgella. Scale bars $500 \mu \mathrm{m}$ for A, C, D and $200 \mu \mathrm{m}$ for E.

lists and lateral apertural rods. They are located regularly below thecal lists and genicular lists (Figs 1B, E, 2A, 3B). The seams on the inside of the horizontal lists are largely hidden (Fig. 1C). Reverse side of ancora sleeve is composed of oblique lists (Figs 1B, E, 2A, 3D).

The seams on virgella indicate the sicula is approximately $2.5 \mathrm{~mm}$ long. Fragment of prosicular apertural rim preserved in one specimen (Fig. 1A) indicates the beginning of metasicula. Prosicular rim is located above genicular list of th $2^{2}$, approximately $2.0 \mathrm{~mm}$ from ancora, above this point the horizontal list is bending and attaches pleural list above genicular list of th $2^{2}$ (Figs 1B, E, F, 2A).

The preservation of material does not demonstrate clearly the connection of the virga to the lateral wall. The virgella attaches the mid-lateral list of the ancora sleeve (Fig. 1C, G, F). It is broken at the level of the geniculum of the th $2^{2}$. Above this point there are last horizontal lists (Fig. 1B, E, F), what may indicates that the virga as well as nema are free. There are no traces of a nema connection to the lateral wall of the ancora sleeve. The specimen of the Virgellograptus perrarus gen. et sp. nov. illustrated on Fig. 2C, D has the distal part of the tubarium preserved. It does not have any traces of a nema incorporated into lateral wall.

From the level of th $2^{2}$ both lateral walls of ancora sleeve become similar, having oblique main lists and reticulum (Fig. 2C, D).

The ventral walls of the tubarium are built on pleural lists, thecal lips, and genicular lists. It is difficult to trace the development of the proximal orifices because of the poor preservation of seams. The proximal orifices are possibly present in early stages of astogeny when the reticulum 

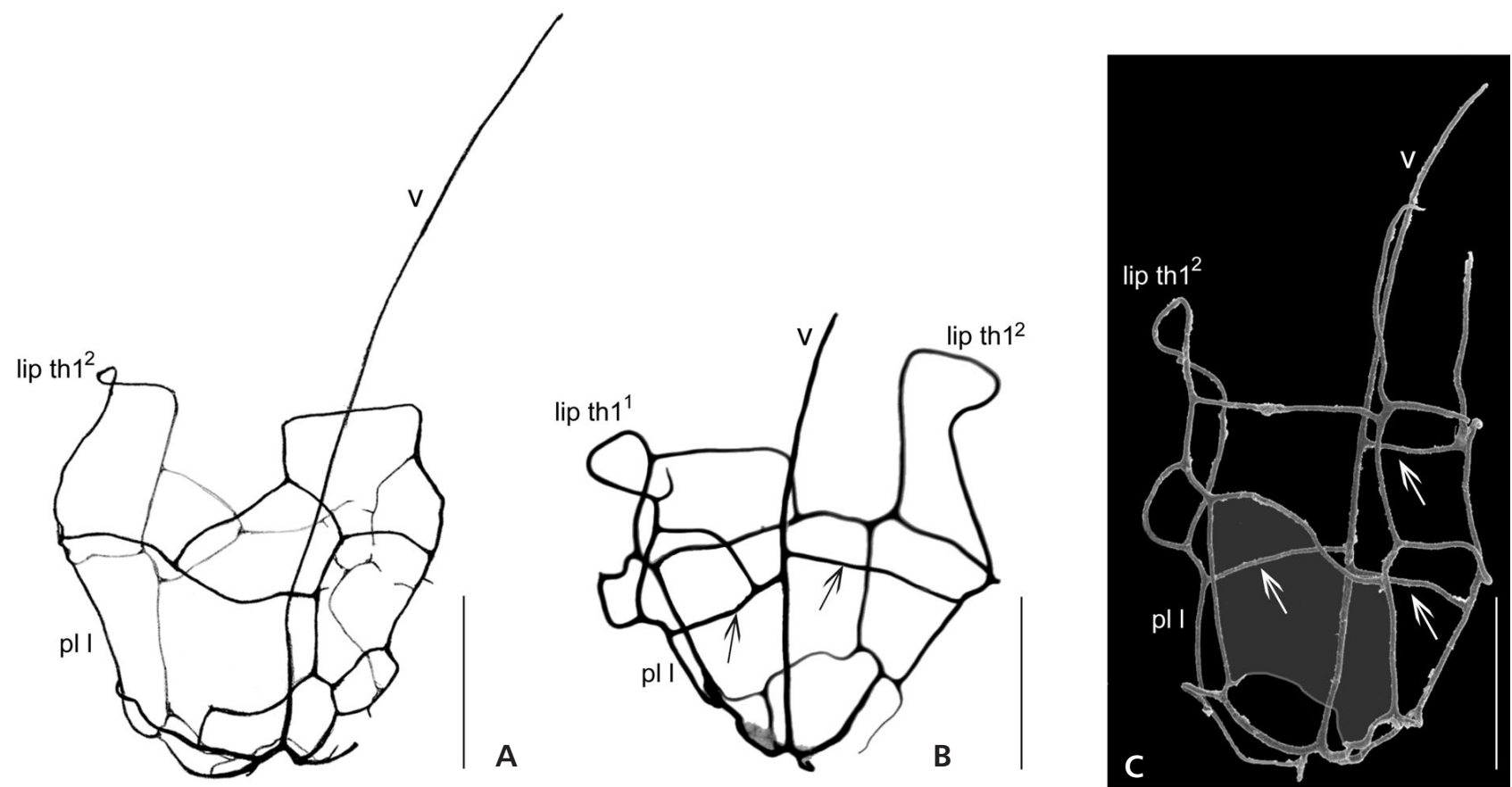

Figure 3. Comparison of young tubaria with the first pair of thecae of Sokolovograptus Obut \& Zaslavskaya, 1976 and Virgellograptus perrarus gen. et sp. nov. A - Sokolovograptus sp. with free virgella, line drawing, 1597.7-1603.1 m, Zawada 1 drill core, Poland, Cyrtograptus perneri Biozone. - B - Virgellograptus perrarus gen. et sp. nov., 1726.5 m, Bartoszyce IG-1 drill core, Cyrtograptus ellesi Biozone, ZPAL G.52/4, light photo, obverse view. $\bullet$ C - Virgellograptus perrarus gen. et sp. nov., 1726.5 m, Bartoszyce IG-1 drill core, Cyrtograptus ellesi Biozone, ZPAL G.52/5, SEM picture, reverse view, probable proximal lateral orifice on reverse side is coloured grey. Arrows show horizontal lists. Abbreviations: pl 1 - pleural list, $\mathrm{v}-\mathrm{virgella}$. A - after Kozłowska-Dawidziuk 1995, fig. 19. Scale bars $500 \mu \mathrm{m}$.

is not developed (Fig. 3C), whereas in mature specimens they are overgrown by reticulum (Figs 1B, E, 2C, D). The reticulum of mature specimens is moderately dense, some secondary lists are very thin (Fig. 1B, C, E, F).

Remarks. - In the majority of isolated retiolitids e.g. Sokolovograptus and Plectograptus Moberg \& Törnquist, 1909, there are no traces of a free nema, such as found in the new form. In those cases it is regarded that the nema is completely free.

Stratigraphic occurrence. - Cyrtograptus ellesi Biozone, Sheinwoodian, mid Wenlock.

Discussion. - Virgellograptus gen. nov. is a unique retiolitid having its virgella connected to the lateral wall of the ancora sleeve. The virgella attaches the vertical list named herein the proximal mid-lateral list, going along the virgella. This kind of proximal end is recognized for the first time.

Similar to the virgella connection to the ancora sleeve, the nema in Gothograptus Frech, 1897 is attached to the obverse lateral wall of the ancora sleeve (see Eisenack 1951, pl. 25; Kozłowska-Dawidziuk 1990, pls 23, 24).

The virgella is linked to the thecal wall of the tubarium by a connecting rod in e.g. Retiolites Barrande, 1850 or
Stomatograptus Tullberg, 1883 (see Bates \& Kirk 1997, figs 1, 5, 6), and Paraplectograptus Přibyl, 1948, which are older and also occur in the same stratigraphic interval as Virgellograptus gen. nov. They belong to the older groups of retiolitids characterized by $e . g$. the ancora sleeve secreted from the inside of the tubarium and a short sicula, in contrast to the younger forms. In these forms, however, the virgella is not incorporated into the lateral wall. It has a central position and a short connecting rod, which is linked to a transverse rod. This is not developed in the new form and thus, the connecting rods of the older forms do not appear to be homologous to the horizontal lists of the Virgellograptus gen. nov.

Virgellograptus gen. nov. is very similar to Sokolovograptus Obut \& Zaslavskaya, 1976, but the key difference is the free virgella in Sokolovograptus. Sokolovograptus forms a separate group of retiolitids, one of the most diverse, having eight species. It is the oldest retiolitid having a free nema, long sicula, and ancora sleeve secreted from the outside; this is regarded as an advanced character (Bates et al. 2005). Sokolovograptus is known from the Cyrtograptus rigidus Biozone of Czech Republic (Bouček \& Münch 1952), the C. perneri Biozone of the Baltic region of Russia (Obut \& Zaslavskaya 1976), the Spirograptus turriculatus/Streptograptus crispus Biozone up to the C. lundgreni Biozone of Arctic Canada (Lenz \& 
Melchin 1987, Lenz et al. 2012), and from the C. perneri (Kozłowska-Dawidziuk 1995) to C. lundgreni biozones (Dobrowolska 2013) of Poland.

Similarities between Virgellograptus gen. nov. and Sokolovograptus are expressed in the construction of the simple ancora umbrella with four meshes (Figs 1B, D, 2B), lateral walls in the medial and distal parts of tubaria having main oblique lists, a free nema, and long sicula. There is a similarity in the shape and ventral wall construction in young growth stages (Fig. 3). The new form is the most similar to $S$. parens Obut \& Zaslavskaya, 1976; S. textor Obut \& Zaslavskaya, 1976, and S. canadensis Lenz, Senior, Kozłowska \& Melchin, 2012 (Lenz et al. 2012). They share a similar proximal end shape, and ventral walls with a reticulum.

Despite the similarities there are several essential differences between the genera. The main differences are the position of virgella connected to the lateral wall of the ancora sleeve, and the presence of well-developed genicular lists in the Virgellograptus gen. nov. Sokolovograptus has well-developed proximal lateral orifices in mature specimens, the opposite of the Virgellograptus gen. nov. where the orifices are overgrown.

Well-developed genicular lists were previously recognized in retiolitid history in Gothograptus, known from the Cyrtograptus perneri-C. rigidus Biozone (KozłowskaDawidziuk 1995), and now in the $V$. perrarus gen. et $\mathrm{sp}$. nov. from $C$. ellesi Biozone. Genicular lists are an advanced feature, characteristic for younger, post-lundgreni retiolitids (Kozłowska-Dawidziuk 2004). In some species of Sokolovograptus, e.g. S. textor, there are some, mostly irregular looping lists on the ventral walls of tubarium, some of them suggestive of genicular lists (Lenz et al. 2012, pl. 4, fig. 1). In some species of Sokolovograptus, e.g. S. polonicus Kozłowska-Dawidziuk, 1995 and S. telleri Kozłowska-Dawidziuk, 1995, only the thecal lips are developed in the ventral walls. Thus the development of the ventral wall of the Sokolovograptus requires further investigation.

Concluding, the outstanding proximal end of the tubarium with the virgella connected to the lateral wall of the ancora sleeve is observed in Virgellograptus perrarus gen. et sp. nov. for the first time in the evolutionary history of retiolitids. This type of the tubarium appeared suddenly, and most probably evolved from a Sokolovograptus species.

\section{Acknowledgements}

I am grateful to Alf Lenz and Denis Bates for discussions and linguistic corrections. Charles Mitchell and Jörg Maletz are greatly thanked for valuable comments which improved the early version of the manuscript. Thanks are given to Aleksandra Hołda-
Michalska for the improvement of some figures. This paper is a contribution to IGCP project 591 "The Early to Middle Palaeozoic Revolution".

\section{References}

Barrande, J. 1850. Graptolites de Bohême. 74 pp. Published by the author, Prague.

BATES, D.E.B. 1990. Retiolite nomenclature and relationships. Journal of the Geological Society 147, 717-723.

DOI 10.1144/gsigs.147.4.0717

BAtes, D.E.B. \& KIRK, N.H. 1984. Autecology of Silurian graptoloids. Special Papers in Palaeontology 32, 121-139.

BATES, D.E.B. \& KIRK, N.H. 1992. The ultrastructure, mode and functioning of a number of Llandovery ancorate and retiolitid graptolites. Modern Geology 17, 1-270.

BAtES, D.E.B. \& KIRK, N.H. 1997. The ultrastructure, mode of construction and functioning of the genera Stomatograptus and Retiolites, with an appendix on the incremental construction of the rhabdosome of Petalolithus, and its comparison with that of the thecal framework in Retiolites and Stomatograptus. Institute of Geography and Earth Sciences, University of Wales, Aberystwyth 10, 1-168.

Bates, D.E.B., KozŁowska, A. \& Lenz, A.C. 2005. Silurian retiolitid graptolites: Morphology and evolution. Acta Palaeontologica Polonica 50, 705-720.

BouČEK, B. \& MÜNCH, A. 1952. Retioliti středoevropského svrchního wenloku a ludlowu. Sborník Ústředního ústavu geologického, Oddíl paleontologický 19, 1-151.

DoBrowolsKa, K. 2013. Evolution of the zooidal behavior and its relation to skeletal structure of the Retiolitidae (Graptolithina). 189 pp. Ph.D. thesis, Institute of Paleobiology, Warsaw, Poland. [in Polish]

EISENACK, A. 1951. Retioliten aus dem Graptolithengestein. Palaeontographica 100, 129-163.

FRECH, F. 1897. Lethaea geognostica oder Beschreibung und Abbildung für die Gebirgsormationen bezeichnendsten Versteinerungen, 544-684. Herausgegeben von einer Vereinigung von Palaeontologen, 1. Teil - Lethaea Palaeozoica. E. Schweizerbart'sche Verlagshandlung, Stuttgart.

Holm, G. 1890. Gotlands graptoliter. Svenska VetenskapAkademiens handlingar 16, 1-34.

KozŁowsKa, A., LenZ, A.C. \& Melchin, M. 2009. Evolution of the retiolitid Neogothograptus (Graptolithina) and its new species from the upper Wenlock of Poland, Baltica. Acta Palaeontologica Polonica 54, 423-434.

DOI 10.4202/app.2008.0022

KozŁowska, A. \& Radzevičius, S. 2013. Upper Homerian and Gorstian (Silurian) Retiolitidae (Graptolithina) from Lithuania and Latvia. Memoirs of the Association of Australasian Palaeontologists 44, 11-23.

KozŁowska, A. \& Urbanek, A. 2013. Bohemograptus papilio sp. nov. three-dimensionally preserved monograptid (Graptolithina) with adaptation to retard sinking, from Upper Silurian, Poland. Comptes Rendus Palevol 12, 13-21.

DOI 10.1016/j.crpv.2012.10.002

KozŁowska-DawiDziuK, A. 1990. The genus Gothograptus 
(Graptolithina) from the Wenlock of Poland. Acta Palaeontologica Polonica 35, 191-209.

KozŁowsKa-Dawidziuk, A. 1995. Silurian retiolitids of the East European Platform. Acta Palaeontologica Polonica 40, 261-326.

KozŁowska-Dawidziuk, A. 1997. Retiolitid graptolite Spinograptus from Poland and its membrane structures. Acta Palaeontologica Polonica 42, 391-412.

KozŁowska-Dawidziuk, A. 2001. Phylogenetic relationships within the Retiolitidae (Graptolithina) and a new Cometograptus genus. Lethaia 34, 84-96.

DOI 10.1080/002411601300068314

KozŁowska-Dawidziuk, A. 2004. Evolution of retiolitid graptolites - a synopsis. Acta Palaeontologica Polonica 49, $505-518$.

LAPWORTH, C. 1873. Notes on the British graptolites and their allies. 1. On an improved classification of the Rhabdophora. Geological Magazine 10, 500-504, 555-560. DOI 10.1017/S0016756800469256

LenZ, A.C. 1993. Late Wenlock and Ludlow (Silurian) Plectograptinae (retiolitid graptolites), Cape Phillips formation, Arctic Canada. Bulletins of American Paleontology 104, 1-52.

LENZ, A.C. 1994a. A sclerotized retiolitid, and its bearing on origin and evolution of Silurian retiolitid graptolites. Journal of Paleontology 68, 1344-1349.

LenZ, A.C. 1994b. Uppermost Wenlock and lower Ludlow plectograptine graptolites, Arctic Islands, Canada: new isolated material. Journal of Paleontology 68, 851-860.

Lenz, A.C. \& KozŁowska, A. 2006. Graptolites from the lundgreni Biozone (Lower Homerian, Silurian), Arctic Islands, Canada: new species and supplementary material. Journal of Paleontology 80(4), 616-637. DOI 10.1666/0022-3360(2006)80[616:GFTLBL]2.0.CO;2

Lenz, A.C. \& KozŁowska-Dawidziuk, A. 2001. Upper Wenlock (Silurian) graptolites of Arctic Canada: pre-extinction, lundgreni Biozone fauna. Palaeontographica Canadiana 20, $1-61$.

LenZ, A.C. \& KozŁowska-Dawidziuk, A. 2002. Upper Homerian (Upper Wenlock, Silurian) graptolites from Arctic Canada. Journal of Paleontology 76, 321-346.

DOI 10.1666/0022-3360(2002)076<0321:UHUWSG >2.0.CO;2

Lenz, A.C. \& KozŁowsKa-Dawidziuk, A. 2004. Ludlow and Pridoli (Upper Silurian) Graptolites from the Arctic Islands, Canada. 141 pp. NRC Research Press, Ottawa, Ontario, Canada.
Lenz, A.C. \& Melchin, M.J. 1987. Silurian retiolitids from the Cape Phillips Formation, Arctic Islands, Canada. Bulletin of the Geological Society of Denmark 35, 161-170.

Lenz, A., Senior, S., KozŁowska, A. \& Melchin, M. 2012. Graptolites from the Mid Wenlock (Silurian), Upper Sheinwoodian, Arctic Canada. Palaeontographica Canadiana 32, $1-93$.

LOYDELL, D.K. 2012. Graptolite biozone correlation charts. Geological Magazine 149, 124-132.

DOI 10.1017/S0016756811000513

Maletz, J. 2008. Retiolitid graptolites from the collection of Hermann Jaeger in the Museum für Naturkunde, Berlin (Germany). I. Neogothograptus and Holoretiolites. Paläontologische Zeitschrift 82, 285-307. DOI 10.1007/BF02988896

MaLeTZ, J. 2010. Retiolitid graptolites from the collection of Hermann Jaeger II: Cometograptus, Spinograptus and Plectograptus. Paläontologische Zeitschrift 84, 501-522. DOI 10.1007/s12542-010-0065-X

Melchin, M.J., Mitchell, C.E., NAczK-Cameron, A., Fan, J.X. \& Loxton, J. 2011. Phylogeny and adaptive radiation of the Neograptina (Graptoloida) during the Hirnantian Mass Extinction and Silurian recovery. Proceedings of the Yorkshire Geological Society 58, 1-30. DOI 10.1144/pygs.58.4.301

Mitchell, C.E. 1987. Evolution and phylogenetic classification of the Diplograptacea. Palaeontology 30, 353-405.

MoberG, J.C. \& TöRnQUIST, S.L. 1909. Retiolitoidea från Skånes Colonus-skiffer. Sveriges Geologiska Undersökning C 213, $1-20$.

MüNCH, A. 1931. Retiolites mancki, ein neuer Retiolites aus dem norddeutschen Geschiebe. Bereich der Naturwissenschaft Gesellschaft zu Chemnitz, 23, 35-42.

Obut, A.M. \& Zaslavskaya, N.M. 1976. New data on the early stages of Retiolitidae development, 119-127. In KaLJo, D. \& Koren', T.N. (eds) Graptolites and Stratigraphy. Academy of Sciences of Estonian SSR, Institute of Geology, Tallinn.

PřIBYL, A. 1948. Bibliographic Index of Bohemian Silurian Graptolites. 96 pp. Knihovna Státního geologického ústavu Československé republiky, sv. 22, Praha.

ТомсZYк, H. 1974. Bartoszyce IG-1, Gołdap IG-1, 1-362. In Moduiński, Z. (ed.) Profile głębokich otworów wiertniczych Instytutu Geologicznego 14.

TUlLBERG, S.A. 1883. Skånes graptoliter. II. Sveriges geologiska Undersökning Afhandlingar C 55, 1-43. 